\title{
New perspectives on the globally important Ediacaran fossil discoveries in Charnwood Forest, UK: Harley’s 1848 prequel to Ford (1958)
}

\author{
Mike P.A. Howe ${ }^{1}$, Mark Evans ${ }^{2,3}$, John N. CARneY ${ }^{1}$ And Philip R. Wilby ${ }^{1}$ \\ ${ }^{1}$ British Geological Survey, Keyworth, Nottingham, NG12 5GG \\ ${ }^{2}$ Leicester Arts and Museums Service, New Walk Museum and Art Gallery, 53 New Walk, Leicester, LE1 7EA \\ ${ }^{3}$ Department of Geology, University of Leicester, Leicester, LE1 7RH \\ Corresponding author (e-mail: mike.howe@cantab.net)
}

SUMMARY: The study of latest Neoproterozoic fossils that comprise the Ediacara biota is a relatively new frontier of palaeontology. That it started when it did is due, in no small measure, to the discovery of macrofossils in Charnwood Forest in 1957, and their description in a paper to the Proceedings of the Yorkshire Geological Society by Trevor Ford in 1958. There is a prequel to this, however: we reveal newly found correspondence showing that as long ago as 1848 enterprising naturalists had seen these macrofossils and recognised them as such. The subsequent rejection of those finds by others mirrors the experiences of geologists elsewhere in the world, and is attributed to a previously received wisdom that macrofossils only occur in Cambrian or younger strata.

A paper to the Proceedings of the Yorkshire Geological Society by Trevor Ford (1958) described remarkable specimens from a fossil locality discovered by a schoolboy, Roger Mason, in 1957 (Ford 2011). Six frondose forms were described and named as a new species, Charnia masoni (Fig. 1a). A further twelve fossils were disc-like, one of which with a frond attached (Fig. 1b), and these types were named Charniodiscus concentricus (Ford 1958). The specimens were compared with fossils of the genus Rangea, from the Nama Group of Namibia (Gürich 1930), and to frondose forms discovered by Sprigg $(1947,1949)$ at the Ediacara locality in South Australia. At the time the Precambrian ${ }^{1}$ age of those fossils could not be confirmed; indeed it was widely supposed that macrofossils only occurred in Cambrian or younger strata. In Charnwood Forest, however, the Charnian Supergroup, as it was subsequently named (Moseley \& Ford 1985), had long been known to be Precambrian in age.

In this article we introduce new documentary evidence for an intriguing prequel to Ford's groundbreaking paper - fossils had been recognised at the same locality in Charnwood Forest in 1848, over a century before Roger Mason's discovery. We then discuss Charles Lapworth's geological observations which had, by 1898, confirmed the Precambrian age of strata equivalent to the fossil-bearing beds in Charnwood Forest. This important finding enabled Ford (1958) to change the accepted scientific interpretation of comparable fossils

\footnotetext{
${ }^{1}$ This article uses the term 'Precambrian', in keeping with the historical literature that will be reviewed. More precisely, however, the period of time in question falls within the latest Ediacaran Period of the Neoproterozoic Era.
} 
from elsewhere in the world. The 1957 discovery, and others from Charnwood Forest that were to follow, provided the first of a series of systematic descriptions of iconic index taxa, thereby establishing the foundation for research into what is now called the 'Ediacara biota'.

$<$ Figs 1a, b $>$

\section{BACKGROUND TO DISCOVERY: DARWIN'S DILEMMA}

The inability of earlier scientists to accept that fossils could be present in rocks pre-dating the Cambrian Period reflects long-standing attitudes, reviewed by Antcliffe \& Brasier (2008), which can be summed up as: a) because Precambrian life was not believed to exist, any fossil-like impressions found in such rocks must be inorganic structures, and b) where unquestionable fossils do occur, the enclosing strata must be Cambrian or younger.

Charles Darwin recognised this problem in his Origin of Species, in a discourse that became known as 'Darwin's Dilemma'. In the first edition (Darwin 1859 p. 307) he wrote: "To the question why we do not find (organic) ${ }^{2}$ records of these vast primordial periods, I can give no satisfactory answer." Darwin's prescience was nevertheless demonstrated by the conclusion that if his theory of evolution by natural selection was correct "... it is indisputable that before the lowest Silurian stratum was deposited, long periods elapsed, as long as, or probably far longer than, the whole interval from the Silurian age to the present day....(when) ${ }^{3}$ the world swarmed with living creatures.” (Darwin 1859 p. 307).

Darwin did draw attention to published descriptions of markings on bedding planes in the Long Mynd, Shropshire (Salter 1856, 1857), adding on p. 307 that: "Traces of life have been detected in the Longmynd beds beneath Barrande's so-called primordial [Cambrian] zone.” These are now acknowledged to include the body fossil Beltanelliformis minutae McIlroy et al. and ichnotaxon Medusinites aff. asteroides Sprigg (McIlroy et al. 2005). They constitute important discoveries, which Callow \& Brasier (2009) suggest "mark the beginning of the study of Precambrian palaeontology..." but historically most workers had regarded them as inorganic impressions (e.g. Greig et al. 1968). They do not include any of the frondose or multi-ringed Ediacaran forms, and perhaps because of this, and also the prevailing contemporary beliefs, their significance has until recently been overlooked.

\section{THE 1848 PREQUEL: THE FIRST FOSSIL FINDS AT CHARNWOOD FOREST}

A manuscript document (Harley 1848) represents the earliest-known account of fossils in rocks that were subsequently confirmed to be Precambrian in age. We also present a second letter, written soon after by J. F. Hollings, which may suggest that Harley was looking for examples of living marine organisms to compare with the fossils.

\subsection{Discovery: the Harley manuscript of April 1848}

James Harley (1801-1860) was a well-regarded active field naturalist whose work is mainly to be found as manuscripts. The letter in question (Harley 1848), to Prof William MacGillivray of Aberdeen University, was found some years ago by one of us (M.E.), when

\footnotetext{
${ }^{2}$ Present authors' addition in parenthesis

${ }^{3}$ Present authors' addition. Note here that during the mid-19th century the oldest fossiliferous beds were at first attributed to the Silurian System, which included the Cambrian 'zone' at its base.
} 
conducting a literature search at the New Walk Museum, Leicester; its more recent retrieval was prompted by correspondence at the end of a paper by Eskrigge (1868; see section 2.3). Harley's letter describes a startling discovery made in a then-recently disused quarry during a visit with a colleague, John Plant. The relevant part of it is shown in Figure 2 and précised as follows:

\section{"Letter II \\ April 1848}

In our way to Leicester abbey. we turned aside from the direct road. for the purpose of making a minute examination of the slate rocks which mark so characteristically that remarkable sylvan part of the County..... It has been admitted, and supported, you know by certain geologists.....that the hypogene or clay slate rocks contain no organic remains, whatever; although of late it has been discovered beyond all contradiction that certain forms have been met with in the Llandiloes flag..... which appear opposed to such conclusions....

...... On the very surface of a large portion of these slate rocks......we observed many circular and spheroid forms at first glance reminding us of certain well known impressions of Ammonites. Several of these figurations we measured, many of which were ascertained by us to exceed five and six inches in diameter. We also observed certain other forms one especially bore some resemblance, we considered, to an Annelid, or rather a vermiform impression. One figuration appeared to the eye in such a style as the following: [for this sketch, see facsimile in Fig. 2] while others resembled at first sight the peculiar seal like impressions of some species of ammonites. But the whole series of figures we observed were irregularly displayed to our view over the entire surface of the rock, the phenomenon having been brought fairly to the eye by the recent operations carried on a number of workmen.......If the peculiar, and remarkable figurations to be seen on these slate rocks forms should prove on closer examination to be organic remains, as I conjecture they may; our small discovery in such a fruitful field of ingenious inquiry, and research, may result in the very fact of certain hypothesis heretofore held as tenable by some writers of modern date, and note, being partly, if not wholly, ignored.”

The "circular and spheroid forms" mentioned above are the bedding plane impressions that caused local people at that time to call this quarry the 'Ring Pit'. Recent findings summarised in Wilby et al. (2011) confirm that these impressions vary greatly in size, and among them the most obvious are three large (30-40 cm diameter), multi-ringed structures (e.g. Fig. 3a).

\section{$<$ Fig. 2>}

\subsection{Research follow-up: the Hollings document of 1850-52}

The descriptions by Harley (1848), and the subsequent research by John Plant mentioned in Ansted (1866, see Section 2.4), show that the impressions had been closely examined and some were even replicated as casts. Those early workers did not, however, elaborate upon the 'other forms' noted by Harley, which we now know must have included the attached fronds (e.g. Fig. 3b), possibly because those parts of the impressions, being of very low relief, had been further obscured by weathering and/or the growth of moss and lichen. Certainly today, 
perhaps less than 20 per cent of what is actually present is obvious on exposures under natural light; the rest only becomes visible on replica moulds or casts viewed in the laboratory, under controlled lighting conditions (compare Figs. 3a \& b).

It is nevertheless possible that Harley's mention of annelid-like or 'vermiform' impressions refers to the segmented and frondose parts of the fossils (Figs. 1a \& b), albeit rather inaccurately sketched (Fig. 2) in his 1848 letter. Some support for this comes from a communication written by John Francis Hollings (1806-1862) to James Harley. This letter was found by one of us (M.H.) in archives at the Record Office for Leicestershire, Leicester and Rutland (reference: 13D56/3), and contains the following advice:

"My dear Sir

Allow me the favour to accept the accompanying Enq. which has been reprinted from the Mercury.

I have now ascertained more exactly the Corallines of which we are in want and which I think the Coast of Aberdeen is most likely to supply. If therefore you should be writing to your friend Dr McGillivray (sic) you will perhaps make interest for us in the matter. The corallines to which I allude are

\author{
Pennatula Phosphorea (Johnstone) \\ Sertularia Nigra \\ Sertularia Rosacea \\ Sertularia Tamarisca \\ Virgularia \\ Believe me \\ My dear Sir \\ Very truly yours \\ J.F. Hollings”
}

The letter is undated, but Hollings took over running the Leicestershire Mercury (a forerunner to the Leicester Mercury) around 1850 (England 1999) and Professor MacGillivray died on $5^{\text {th }}$ September 1852, so it seems likely that it was written between 1850 and 1852 . The published enquiry has not yet been traced.

Although other explanations are possible, the very timing of this letter suggests that Hollings was assisting in a search for examples of extant pennatulid species to compare with the Charnwood finds communicated in Harley's 1848 letter (Fig. 2). Sertularia is a hydrozoan from the same phylum as sea pens (Cnidaria), whereas Virgularia and Pennatula phosphorea Linnaeus are modern sea pens of the subclass Octocorallia; all of these modern organisms superficially resemble Charnia masoni Ford. In this regard, it is doubly significant that John Plant, who had ample opportunity to study his casts under controlled lighting conditions, was also favouring an interpretation as coral-like organisms, although this was only casually attributed to him in a later document by Ansted (1866, see Section 2.4 below). A possible reason why such deliberations never entered the literature is that with John Plant's move to Salford in October 1849, and MacGillivray's death in 1852, neither Harley nor Plant had the support to continue this research. 
Ford (1958) suggested that Charnia may have been an algal organism; however, Ford (1963) and Boynton \& Ford (1995) noted that subsequent workers (e.g. Glaessner 1959) favoured greater affinity with cnidarians such as pennatulids. Harley may thus have been pursuing a similar line of research to that of palaeontologists working a century later. The analogy between sea pens and Charnia has only recently been rejected, by Antcliffe \& Brasier (2007), on the basis of major differences in growth patterns between the two.

\section{$<$ Figs. 3a, b $>$}

\subsection{Early support for the discovery: John Plant and Prof. A. C. Ramsay}

Articles supporting Harley's interpretation of his Charnwood finds also provide an insight on the types of organism they were thought to represent. The earliest, on p. 19 of a catalogue by Ramsay et al. (1862), seems to be the first published suggestion that Charnian rocks could contain organic features, although in modern nomenclature the latter would be classified as trace fossils:

"No fossils have yet been found in the supposed Cambrian beds (of Charnwood Forest), except impressions that seem to have been made by the waving of sea-weeds, and the true date of the beds is, therefore, doubtful. They have been classed, in fact, with the Cambrian rocks simply on account of their lithological characters.”

Contrary to various publications (e.g. McCall 2006, p. 9), there is no mention of the 'seaweeds' in the $1^{\text {st }}$ edition of their catalogue (Ramsay et al. 1858) nor the $2^{\text {nd }}$ edition (Ramsay et al. 1859, 1860).

A later document, found at the British Geological Survey by Frank Ince, brings Harley's 1848 discovery to more general attention in the form of a discussion by a 'Mr. Plant'. This was published on p. 56 at the end of a short paper by Eskrigge (1868), as follows:

"The only traces of organic remains which have been found in the slate rocks are the remarkable rings.....discovered by myself and the late Mr. James Harley, in April, 1848. They occur with two raised rings, commencing with a kind of projecting boss, going round, and varying in diameter from six inches to one foot. Professor Ramsay's opinion is that they were very likely spots where large seaweeds had been rooted, and probably by the reaction of the seaweed bending round by the force of the water, scooping out the mud in concentric circles. The hypothetical view of the geology of Charnwood is that it is related to the Welsh strata; but no specimens have been obtained from Charnwood Forest identical with those of the Cambrians from North Wales. In Professor Ansted's recent Memoir of the Geology of Charnwood Forest the subject is fully discussed, but not decided.”

This note reiterates the organic interpretation of these impressions given in Ramsay et al. (1862), detailed above. Although it did not state Plant's Christian name, the correspondent had noted (p. 55): "The geology of Charnwood Forest is perfectly familiar to me, from having been the field of many years' careful exploration before I came to Manchester.” This is significant, because the Manchester Geological Society Membership list for the time includes a Mr John Plant as an Honorary Member. John Plant (1819 - 1894) was born in Leicester and in 1844 was elected Honorary Secretary of the Leicester Naturalists' Club; shortly afterwards he was appointed Curator of the museum founded by the Leicester Literary 
and Philosophical Society, which forms the basis of the present New Walk Museum, Leicester. He then became Curator and Chief Librarian of the Peel Park Museum, Salford, in October 1849. John's brother, Nathaniel (1832-1875) replaced him as Curator before leaving in 1851 for Brazil, where he explored the Candiota coal fields. Another brother, James Plant FGS (c.1817-1892) became well-known as a geologist in Leicester, and was the Honorary Curator for Geology at the museum from 1872 to 1876.

\subsection{Doubts begin to surface: Ansted, 1866}

Plant's note in Eskrigge (1868) included reference to a passage in the Palaeontology section of Ansted (1866, p. 47-48). This provides fascinating information on John Plant's involvement, but it also strikes a dismissive note concerning the organic affinities of these impressions:

“...there are at present no known markings on any of the slate-rocks of Charnwood, except a few curious and regular concentric furrows on the plane of bedding, in one of the quarries at Swithland. Considerable attention was paid to these by Mr J. Plant of Leicester, immediately after their discovery, several years ago, when the face of the quarry was first bared. Casts were also taken by him of the most remarkable specimens. ${ }^{4} \mathrm{Mr}$ Plant imagined them to be coral. Professor Ramsay suggested that they might be sea-weeds. Neither suggestion is altogether satisfactory. They are concentric ridges and furrows - several in number in each case. Three or four good specimens were seen, and there were others less perfect on the same exposed face of rock. They were all within an area of a few hundred square yards, and, though visible, not very accessible. In their present weathered state it is less easy than when they were first discovered to make out their meaning.*”

The asterisk at the end of the passage refers to a footnote at the bottom of page 48 of Ansted (1866). This draws attention to the then-recent description of "Eozoön canadense", which Dawson (1865) considered to be a giant foraminifera, found in 'Laurentian' limestones in Canada. This occurrence seemed to provide the evidence for Precambrian life sought after by notable scientists of the time, including Charles Darwin, but it was very soon correctly reinterpreted as a type of metamorphic rock-fabric (King \& Rowney 1866).

Our searches have failed to locate the casts highlighted in the above passage. There is no record of them at the New Walk Museum at Leicester. John Plant donated some material to the Salford Museum, but all the geological specimens held there were dispersed to other museums in the northwest of England (mainly Manchester, Bolton \& Stockport museums) during the 1980s, together with the remaining natural history collections (Peter Ogilvie, Collections Manager, Salford Museum \& Art Gallery, personal communication, 2008). There is a record (Surrey Museums Consultative Committee 2006) listing John Plant as a collector of material (1856 specimens) at the King Edward VI School, Witley, Godalming, Surrey; however, this collection has now been dispersed, largely to the Haslemere Educational Museum, a search through the records of which has also proved to be fruitless.

\subsection{Dismissal of the fossils: 1877 and later}

\footnotetext{
${ }^{4}$ Present authors' italics
} 
It is possible that later authors may have been influenced by the Eozoön canadense controversy referred to above, and the subsequent general rejection by the geological community that Precambrian fossils could exist. Thus Hill \& Bonney (1877) dismissed the organic interpretation of the rings with this passage:

"On one of the great bedding faces are seen two of those curious arrangements of concentric rings which have been supposed to be organisms. The resemblance to any known organism is of the most superficial character; and one objection seems fatal. They lie in the plane of bedding, which makes a high angle with that of cleavage. Though the latter is well marked, the rings suffer no distortion. The larger, which is about seven inches in diameter, consists of about three rather rippled concentric flat rings; the smaller is only about two inches in diameter. We regard them as an accidental structure, due to some local peculiarity, but have a decided opinion only on one point, viz. that they are inorganic.”

Their 'fatal' objection seems to have been that the rings, being apparently undeformed, must post-date the cleavage and thus be inorganic. This observation is, however, inaccurate: the cleavage pervades the whole outcrop, including the fossil impressions, from which the present authors have measured strain ratios of typically 1.25. Moreover, the deformation event that caused the cleavage has been isotopically dated to end-Silurian times (Carney et al. 2008).

There are only a few later, dismissive, mentions of the 'rings'; for example Watts (1947) noted that "Curious concretionary markings found in this quarry have been considered to be possibly fossils, but Hill and Bonney have effectually disposed of their claim to be organic (1877, p.757).”

\section{PROVING THE AGE OF THE CHARNIAN: CHARLES LAPWORTH (1898)}

The repercussions of Ford (1958) not only revolved around the fossil discovery, but the Precambrian age of the strata that enclosed them. Crucial to determining this were the investigations by Charles Lapworth at Nuneaton, and the extension of his findings to Charnwood Forest, because until that time the antiquity of the Charnian rocks had only been hinted at. For example, Holl (1865) had stated in a footnote to a paper on the Malverns that: “...by whatever name they may be distinguished, however, they [i.e. the Malverns] are part of the old pre-Cambrian continent, of which the metamorphic rocks north of the River St. Lawrence.....etc. and probably of Charnwood Forest....are uncovered areas.”

In the late $19^{\text {th }}$ century, quarrying operations at Nuneaton, $20 \mathrm{~km}$ to the south-west of Charnwood Forest, were revealing volcaniclastic rocks which Lapworth (1898) called the 'Caldecote Volcanic Series' (now the Caldecote Volcanic Formation). They occurred beneath strata of the Hartshill Sandstone Formation (Lapworth's 'Hartshill Quartzite'), which in turn is overlain by the Stockingford Shale Group (e.g. Bridge et al. 1998). In earlier geological surveys these two upper sedimentary divisions had been assigned a Carboniferous age, but this was revised when Lapworth $(1882,1886)$ discovered Cambrian fossils in the Stockingford Shale Group.

The Precambrian age of the underlying volcaniclastic rocks was finally confirmed when Lapworth (1898) found Early Cambrian shelly fossils in the 'Hyolite-Limestone', subsequently 
named the 'Home Farm Member' by Brasier et al. (1978). The stratigraphical position of this fauna, near the top of the 250 m-thick Hartshill Sandstone Formation, combined with the considerable difference in lithology between the latter and the underlying Caldecote Formation, left Lapworth in little doubt that a "long interval of time" had elapsed between the two sequences (Lapworth 1898). This conclusion is corroborated by exposures showing deep weathering of the Caldecote Formation beneath the Hartshill Sandstone (Fig. 4). The unconformity is exposed elsewhere in the English Midlands, and represents a hiatus of at least 30 million years of geological time.

Lapworth (1898) asserted that not only the Caldecote Formation, but by extension, the basement rocks of Charnwood Forest pre-dated the Cambrian Period; a correlation accepted by all subsequent workers. He was supported in this by his contributing author, who later (Watts 1947) drew attention to the discovery of a distinctive granophyric diorite intrusion into the Caldecote succession (Jones 1935). Not only is the Nuneaton diorite petrographically identical to the 'markfieldite' of Charnwood Forest ('South Charnwood Diorite' of Worssam \& Old 1988), which is intruded into the fossil-bearing Maplewell Group strata, but its Precambrian age is confirmed by the observation that it is overlain with erosional unconformity by the Hartshill Sandstone (Wills \& Shotton 1934; Bridge et al. 1998).

\section{$<$ Fig. 4 >}

\section{GLOBAL SIGNIFICANCE OF THE CHARNWOOD DISCOVERIES}

Throughout the world, palaeontologists had been presented with evidence for Precambrian life as far back as Salter's 1856 discoveries in the Long Mynd referred to by Darwin (see above). These fossils, however, were either dismissed as inorganic, or the rocks they occurred in attributed to Cambrian or younger ages, as reviewed in Fedonkin et al. (2007).

Such attitudes were demonstrated when fossils were first found in what was to become the type locality for the Ediacara biota, in the Ediacara Hills of South Australia. That discovery was made by Reginald Sprigg in 1946, but according to Gehling \& Vickers-Rich (2007) he received nothing but scepticism from his peers; firstly over the biological affinities of these discoveries and then, when they were shown to be fossils, over their suggested Precambrian age.

The earliest publications of Sprigg $(1947,1949)$ show that he was compelled to settle for an Early Cambrian age for the enclosing strata. This conclusion was overturned, however, when Ford (1958) noted that the new Charnwood Forest fossils were comparable to some of those described by Sprigg. As recounted by Gehling \& Vickers-Rich (2007): "With Ford's paper it suddenly became obvious that these fossils might occur in Precambrian rocks worldwide." Local workers were galvanised and a paper was published by Glaessner (1958). The Ediacara fossiliferous strata continued to be regarded as earliest Cambrian for a while, but were later shown to be separated from undoubted Cambrian rocks by an erosional unconformity. A paper then followed (Glaessner 1959), the first of many describing Precambrian 'jellyfish' fossils and comparing them with similar examples from Africa and England.

\subsection{Constraining the Precambrian-Cambrian boundary}

The issue over precisely when and at which datum the Precambrian ended and the Phanerozoic began has only recently been resolved, but is of vital importance to Precambrian 
palaeontology. As reviewed by Bowring \& Martin (1999), ages between 590 and 570 Ma had been considered for this boundary, in which case many fossil horizons containing Ediacara biota would have been placed within the Cambrian Period.

The problem was addressed by Project No. 29 of the IGCP, which decided that the GSSP (Global Stratotype Section and Point) for this boundary was to be the coastal exposure at Fortune Head, Newfoundland. Not only did this section offered an unbroken sedimentological transition between Precambrian and Early Cambrian strata, but it also contained a rich assemblage of trace and body fossils. The Precambrian-Cambrian boundary point (i.e. the earliest point in the Cambrian Period) was accordingly defined by Brasier et al. (1994) to be the datum containing the stratigraphically lowest occurrence of the trace fossil Phycodes (now Treptichnus) pedum Seilacher. A boundary age of around 544 Ma was estimated by Brasier et al. (1994) from uranium-series geochronological determinations then available from various parts of the world.

More precise age constraints followed from U-Pb zircon determinations on the Schwarzrand Subgroup of Namibia, where strata bracketing the incoming of more complex spiral trace fossils, such as Phycodes (Treptichnus) pedum, indicated that the Precambrian-Cambrian boundary was younger than $543.3 \pm 1$ Ma and older than $539.4 \pm 1 \mathrm{Ma}$ (Grotzinger et al. 1995). The date of 542.6 \pm 0.3 Ma currently accepted by Van Kranendonk et al. (2008), is from a U-Pb zircon determination within the Ara Group of Oman (Amthor et al. 2003).

For Charnwood Forest a preliminary U-Pb (TIMS) age of $563 \pm 1.9$ Ma (data from the British Geological Survey-Natural Environment Research Council Isotope Geoscience Laboratories) has been obtained from zircons just below one of the principal fossiliferous levels in the Bradgate Formation, Maplewell Group (stratigraphy of Moseley \& Ford 1985). This is within the error limits of a U-Pb zircon age of $565 \pm 3$ Ma (Benus 1988) for the Ediacaran fossil horizon at Mistaken Point in Newfoundland, with which the Charnian 'Mercian Assemblage' of fossils is closely comparable (Wilby et al. 2011).

\section{CONCLUSIONS}

The major finding of this study is that Charnwood Forest was the site of a palaeontological discovery that was over a century ahead of its time. The documentation of 'rings' and recognition of their organic nature by Plant and Harley in 1848 constituted the first record anywhere of macrofossils in strata that were later to be determined as Precambrian in age. A further archived letter documents a search by Harley for examples of modern Pennatulacea, which resemble Charnia, possibly providing supporting evidence that he had also observed frondose fossil forms. Charles Darwin was unaware of this find, but in his Origin of Species (1859) stated that Precambrian life must have existed. This prophetic announcement unfortunately did not provide a direction to further palaeontological field observation and by 1877 the organic explanation of the Charnwood 'rings' had been dismissed. Such attitudes are attributed to a general perception that fossils could not exist in 'ancient' rocks, and were possibly influenced by the Eozoön canadense controversy of 1865.

Harley's find was the prequel to Roger Mason's discovery in 1957, which in turn led to the paper by Ford (1958) proving beyond doubt that the macrofossils he named as Charnia and Charniodiscus were of Precambrian age. It is fully justifiable to consider the paper by Ford (1958) as the crucial point in a paradigm shift, because it provided the means whereby other 
pioneering workers could confirm the antiquity of their own finds. The age of similar fossils in South Australia was revised downwards, from Cambrian to late Precambrian (Glaessner 1959), and from that particular locality the name 'Ediacara biota' has been coined. The subsequent recognition of other late Precambrian fossil sites worldwide (Fedonkin et al. 2007) in large part relied upon comparisons with index taxa established in Charnwood Forest.

More fossils were subsequently reported from Charnwood Forest (e.g. Boynton \& Ford 1995 and references therein; Ford 1963; 1999) and hundreds of new specimens have recently been discovered (Wilby et al. 2011) in what had previously been regarded as a sparse assemblage, promising a renaissance of ideas about the earliest diverse macroscopic life-forms to inhabit the planet.

Acknowledgements. We thank Trevor Ford, Helen Boynton and Frank Ince for the provision of information, and the former two for encouragement and reviews of this article. Adam Goodwin and the staff of the Record Office for Leicestershire, Leicester \& Rutland are gratefully acknowledged for their assistance in numerous searches, as are staff of the library at BGS Keyworth and the National Geoscience Data Centre for locating various maps and catalogues. We are grateful to BGS internal reviewers John Powell and Mark Woods, and to Journal reviewers Jan Zalasiewicz and Trevor Ford for their valuable comments on earlier drafts of this article. Mike Howe, John Carney and Philip Wilby publish by permission of the Executive Director, British Geological Survey (NERC).

\section{REFERENCES}

AMTHOR, J. E., GROTZINGER, J. P., SCHRODER, S., BOWRING, S. A., RAMEZANI, J., MARTIN, M. W. \& MATTER, A. 2003. Extinction of Cloudina and Namacalathus at the Precambrian-Cambrian boundary in Oman. Geology, 31, 431-434.

ANSTED, D. T. 1866. The Physical Geography and Geology of the County of Leicester. (London: Nichols and Sons), 88 pp.

ANTCLIFFE, J. B. \& BRASIER, M. D. 2007. Charnia and sea pens are poles apart. Journal of the Geological Society of London, 164, 49-51.

ANTCLIFFE, J. B. \& BRASIER, M. D. 2008. Charnia at 50: Developmental models for Ediacaran fronds. Palaeontology, 51, 11-26.

BENUS, A. P. 1988. Sedimentological context of a deep-water Ediacaran fauna (Mistaken Point, Avalon Zone, eastern Newfoundland). In: LANDING, E. (ed.) trace fossils, small shelly fossils and the Precambrian-Cambrian boundary. New York State Museum and Geological Survey Bulletin, 463, 8-9.

BOWRING, S. A. \& MARTIN, M. W. 1999. High precision U-Pb geochronology, the tempo of evolution and the record from Gondwana. Journal of African Earth Sciences, 28, 187-201.

BOYNTON, H. E. \& FORD, T. D. 1995. Ediacaran fossils from the Precambrian (Charnian Supergroup) of Charnwood Forest, Leicestershire, England. Mercian Geologist, 13, 165-183. 
BRASIER, M. D., HEWITT, R. A. \& BRASIER, C. J. 1978. On the late Precambrian-early Cambrian Hartshill Formation of Warwickshire. Geological Magazine, 115, 21-36.

BRASIER, M. D., COWIE, J. \& TAYLOR, M. 1994. Decision on the Precambrian-Cambrian boundary stratotype. Episodes, 17, 95-100.

BRIDGE, D. McC., CARNEY, J. N., LAWLEY, R. S. \& RUSHTON, A. W. A. 1998. The geology of the country around Coventry and Nuneaton. Memoir of the British Geological Survey, Sheet 169 (England and Wales), 185 pp.

CALLOW, R. H. T. \& BRASIER, M. D. 2009. A solution to Darwin's dilemma of 1859: exceptional preservation in Salter's material from the late Ediacaran Longmyndian Supergroup, England. Journal of the Geological Society of London, 166, 1-4.

CARNEY, J. N., ALEXANDRE, P., PRINGLE, M. S., PHARAOH, T. C., MERRIMAN, R. J. \& KEMP, S. J. 2008. ${ }^{40} \mathrm{Ar}-{ }^{39} \mathrm{Ar}$ isotope constraints on the age of deformation in Charnwood Forest, UK. Geological Magazine, 145, 702-713.

DARWIN, C. 1859. On the Origin of Species by means of Natural Selection, or the Preservation of favoured Races in the Struggle for Life. (London: John Murray, $1^{\text {st }}$ edition), 502 pp.

DAWSON, J. W. 1865. On the structure of certain organic remains in the Laurentian limestones of Canada. Quarterly Journal of the Geological Society of London, 21, 51-59.

EnGlAnd, S. 1999. Magnificent Mercury: History of a regional newspaper. (Newtown Linford, Leicester: Kairos Press), 140 pp.

ESKRIGGE, R. A. 1868. Geological notes made during a tour in Leicestershire Transactions of the Manchester Geological Society, 7, (5), 51-57

FEDONKIN, M. A., GEHLING, J. G., GREY, K., NARBONNE, G. M. \& VICKERS-RICH, P. (eds) 2007. The Rise of Animals: evolution and diversification of the Kingdom Animalia. (Baltimore, USA: The John Hopkins University Press), 326 pp.

FoRD, T. D. 1958. Precambrian fossils from Charnwood Forest. Proceedings of the Yorkshire Geological Society, 31, 211-217.

ForD, T. D. 1963. The Pre-Cambrian fossils of Charnwood Forest. Transactions of the Leicester Literary and Philosophical Society, 57, 57-62.

FORD, T. D. 1999. The Precambrian fossils of Charnwood Forest. Geology Today, November-December, 230-234.

FORD, T. D. 2011. Discovery of the Precambrian fossils in Charnwood Forest. Mercian Geologist, 17, 226-227.

GEHLING, J. G. \& VICKERS-RICH, P. 2007. The Ediacara Hills In: Fedonkin, M. A., Gehling, J. G., Grey, K., Narbonne, G. M. \& Vickers-Rich, P. (eds) The Rise of Animals: 
evolution and diversification of the Kingdom Animalia. (Baltimore, USA: The John Hopkins University Press), 89-114.

GLAESSNER, M. F. 1958. New fossils from the base of the Cambrian in South Australia. Transactions of the Royal Society of South Australia, 81, 185-188.

GLAESSNER, M. F. 1959. Precambrian Coelenterata from Australia, Africa and England. Nature, 183, 1472-1473.

GREIG, D. C., WRIGHT, J. E., HAINS, B. A. \& MITCHELL, G. H. 1968. Geology of the country around Church Stretton, Craven Arms, Wenlock Edge and Brown Clee. Memoir of the British Geological Survey, Sheet 166 (England and Wales).

GROTZINGER, J. P., BOWRING, S. A., SAYLOR, B. Z. \& KAUFMAN, A. J. 1995. Biostratigraphic and geochronological constraints on early animal evolution. Science, 270, 598-604.

GÜRICH, G. 1930. Die bislang altesten Spuren von Organismem in Sudafrick. International Geological Congress of South Africa 1929, 15, 670-880.

HARLEY, J. 1848. Manuscript page from a book entitled: "A synopsis of the vertebrated Animals of the County of Leicester, arranged according to the classification of Jenyns; to which is added remarks on the periodical arrival of several Summer birds of passage with notes and Observations thereupon. 1840-1855." Catalogued as LEICT 16L1923. (Leicester: New Walk Museum).

HILL, E. \& BONNEY, T. G. 1877. The Pre-Carboniferous rocks of Charnwood Forest. Quarterly Journal of the Geological Society of London, 33, 754-789.

HOLL, B. B. 1865. On the geological Structure of the Malvern Hills and adjacent districts. Quarterly Journal of the Geological Society of London, 21, 72-102.

JONES, F. 1935. The occurrence of Markfieldite at Nuneaton. Geological Magazine, 72, 9193.

KING, W. \& ROWNEY, T. H. 1866. On the So-called 'Eozoonal Rock'. Quarterly Journal of the Geological Society of London, 22, 185-218.

LAPWORTH, C. 1882. On the discovery of Cambrian rocks in the neighbourhood of Birmingham. Geological Magazine, 9, 563-565.

LAPWORTH, C. 1886. On the sequence and systematic position of the Cambrian rocks of Nuneaton. Geological Magazine, I3, 319-322.

LAPWORTH, C. 1898. Sketch of the geology of the Birmingham District. Proceedings of the Geologists Association, 15, 313-389.

McCALL, G. J. H. 2006. The Vendian (Ediacaran) in the geological record: Enigmas in geology’s prelude to the Cambrian explosion. Earth Science Reviews, 77, 1-229. 
McILROY, D., CRIMES, T. P. \& PAULEY, J. C. 2005. Fossils and matgrounds from the Neoproterozoic Longmyndian Supergroup, Shropshire, UK. Geological Magazine, 142, 441455.

MOSELEY, J. \& FORD, T. D. 1985. A stratigraphic revision of the Late Precambrian rocks of the Charnwood Forest, Leicestershire. Mercian Geologist, 10, 1-18.

RAMSAY, A. C., BRISTOW, H. W. \& BAUERMAN, H. 1858. A Descriptive Catalogue of the Rock Specimens in the Museum of Practical Geology. (London: HMSO for Geological Survey of Great Britain), 332 pp.

RAMSAY, A. C., BRISTOW, H. W., BAUERMAN, H. \& GEIKIE, A. 1859. A Descriptive Catalogue of the Rock Specimens in the Museum of Practical Geology. Second edition, with additions.

(London: HMSO for Geological Survey of Great Britain). 375 pp.

RAMSAY, A. C., BRISTOW, H. W., BAUERMAN, H. \& GEIKIE, A. 1860. A Descriptive Catalogue of the Rock Specimens in the Museum of Practical Geology. Second edition. (London: Eyre \& Spottiswoode). 296 pp.

RAMSAY, A. C., BRISTOW, H. W., GEIKIE, A. \& BAUERMAN, H. 1862. A descriptive catalogue of the rock specimens in the Museum of Practical Geology, with explanatory notices of their nature and mode of occurrence in place. Third edition, revised and partly rewritten. (London: HMSO for Geological Survey of Great Britain), 291 pp.

SAlter, J. W. 1856. On Fossil Remains in the Cambrian Rocks of the Longmynd and North Wales. Quarterly Journal of the Geological Society, London, 12, 246-251

SAlteR, J. W. 1857. On Annelide-burrows and Surface-markings from the Cambrian Rocks of the Longmynd No. 2. Quarterly Journal of the Geological Society, London. 13, 199-206

SPRIGG, R. G. 1947. Early Cambrian (?) jellyfishes from the Flinders Ranges, South Australia. Transactions of the Royal Society of South Australia, 71, 212-224.

SPRIGG, R. G. 1949. Early Cambrian “jellyfishes” of Ediacara, South Australia, and Mount John, Kimberley District, Western Australia. Transactions of the Royal Society of South Australia, 73, 72-99.

Surrey Museums Consultative Committee. 2006. (Collections. Geology) King Edward VI School. Web page (consulted $6^{\text {th }}$ January 2008). http://www.surreymuseums.org.uk/collections/geology/geo11.html.

VAN KRANENDONK, M. J., GEHLING, J. \& SHIELDS, G. 2008. Precambrian. In: Ogg, J. G, Ogg, G. \& Gradstein, F. M. (eds) The concise geologic time scale. (USA: Cambridge University Press), 177 pp.

WATTS, W. W. 1947. Geology of the ancient rocks of Charnwood Forest, Leicestershire. (Leicester: Leicester Literary and Philosophical Society), 160 pp. 
WILBY, P. R., CARNEY, J. N. \& HOWE, M. P. A. 2011. A rich Ediacaran assemblage from eastern Avalonia: evidence of early widespread diversity in the deep. Geology, 39, 655-658.

WILLS, L. J. \& SHOTTON, F. W. 1934. New sections showing the junction of the Cambrian and Precambrian at Nuneaton. Geological Magazine, 71, 512-521.

WORSSAM, B. C. \& OLD, R. A. 1988. Geology of the country around Coalville. Memoir of the British Geological Survey, Sheet 155 (England and Wales), 161 pp.

\section{FIGURE CAPTIONS}

1. Images of the holotypes from Ford (1958). (A) Charnia masoni Ford (length $=21$ $\mathrm{cm}$ ), (B) Charniodiscus concentricus Ford (stem is $25 \mathrm{~cm}$ in length from centre of holdfast to tip of frond). These fossils occur on a bedding plane in distal-facies volcaniclastic turbidites in the upper part of the Bradgate Formation, Charnian Supergroup (for stratigraphical nomenclature see Moseley \& Ford 1985; Worssam et al. 1988).

2. Page from a letter dated April 1848, written by James Harley to Prof William MacGillivray of Aberdeen University and including a sketch of a possible 'annelid' trace.

3. The Charnwood 'ring' structures. (A) Large multi-ringed impression photographed at outcrop when rediscovered in 2007, (B) Obliquely illuminated plaster cast of the same structure showing the attached stem and frond; this is a new and as yet unnamed species (from Wilby et al. 2011). The ringed holdfast structure measures 22 × $27 \mathrm{~cm}$ in diameter and the stem and frond rising from it together measure $38 \mathrm{~cm}$ in length.

4. The Precambrian-Cambrian unconformity at Boon's Quarry, Nuneaton (Picture (C) BGS; photo No. P213635). The figure is standing on Precambrian rocks of the Caldecote Volcanic Formation, which is overlain by stratified basal Lower Cambrian breccias of the Boon's Member, Hartshill Sandstone Formation. The breccias contain large, rounded core-stones (e.g. top left) detached from the spheroidally weathered Precambrian palaeo-landsurface (Bridge et al. 1998). 


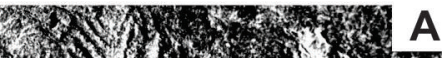

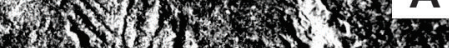

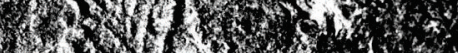

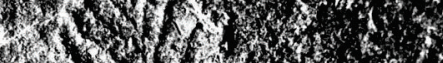

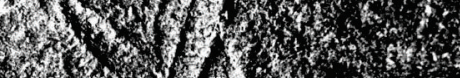

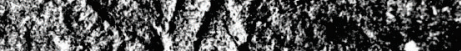

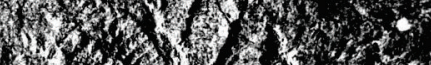

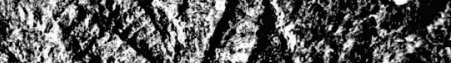

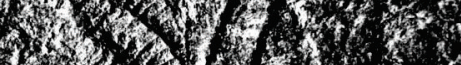

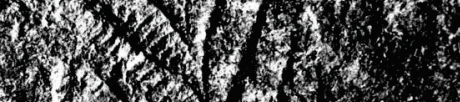

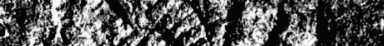
Wh

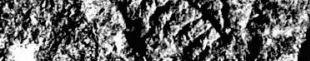

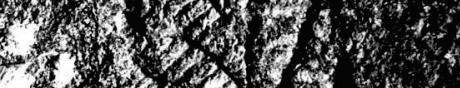

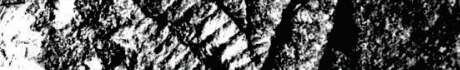

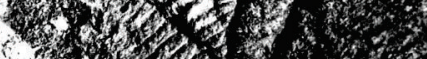
wown W

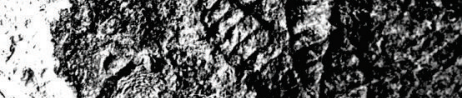

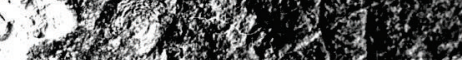
1710 1.7.7.

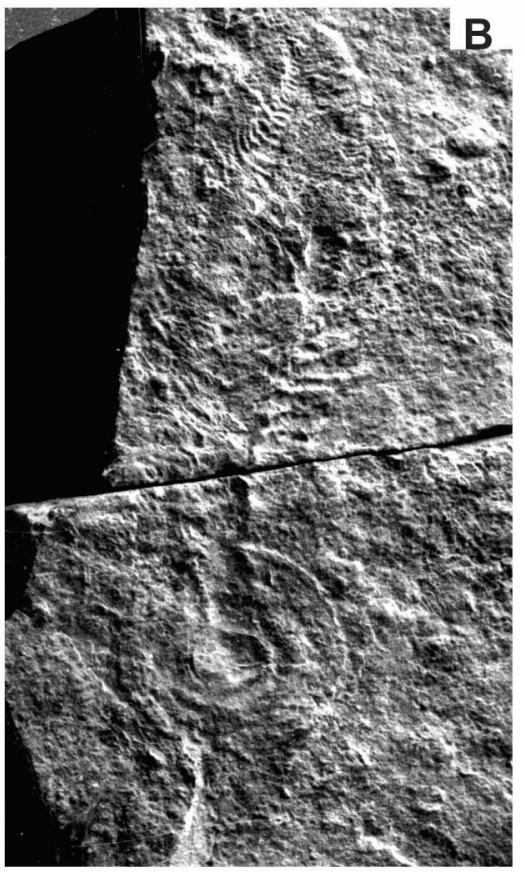


390

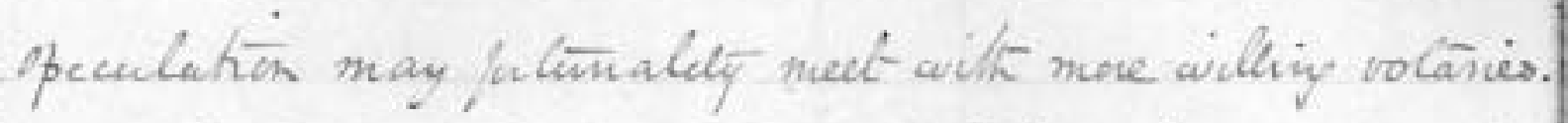

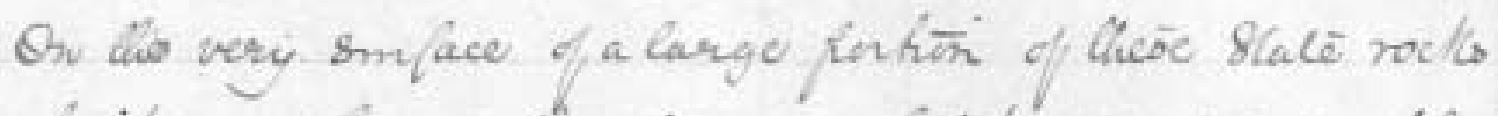
to aluith we kave ufured, are aluich we were cancul to scamine, we obeurd many cercular are sphereid, mo

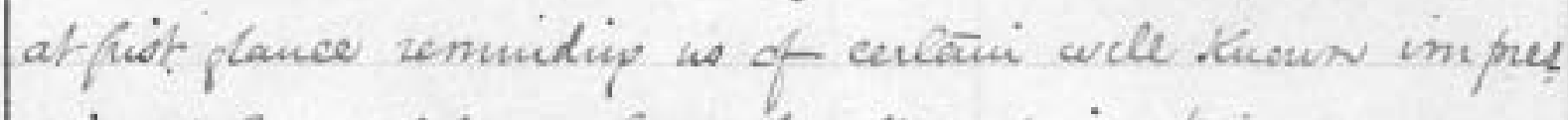

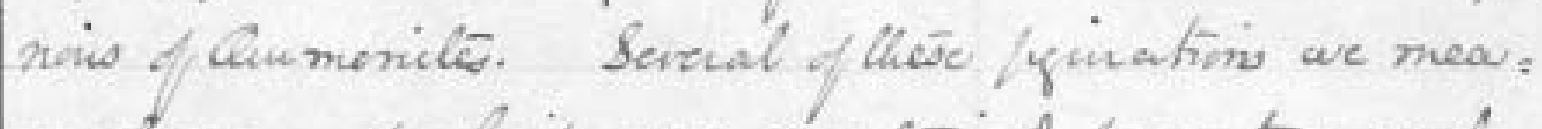
mond, many of aluit were ascentanied by no to seceed

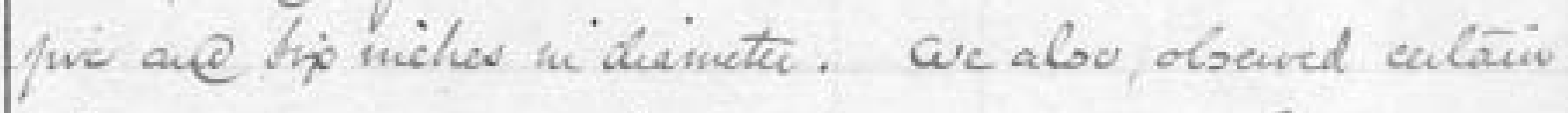
other fomw -ove sopecialey bre some woulcauce, wo considend, te an Auncliel, on nuther avermiform mis. freosion. One jyiration appeased to aceye in such a

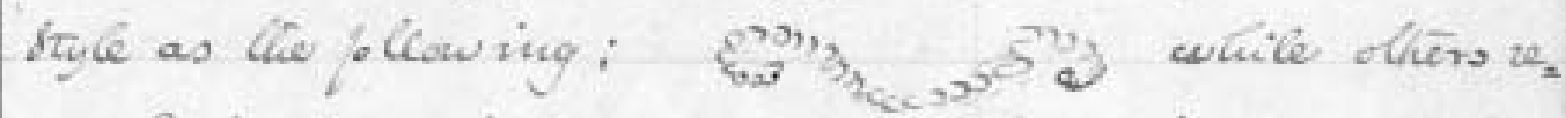

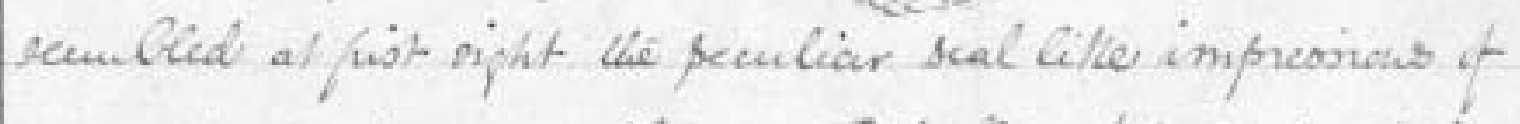

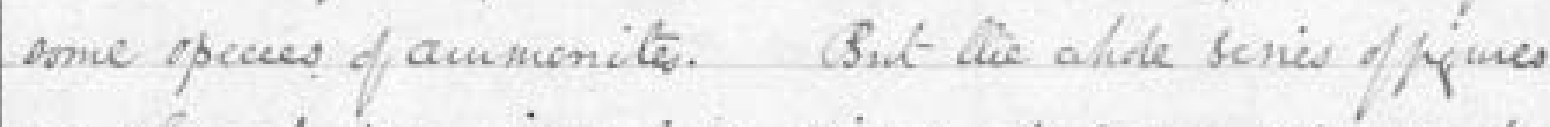
we obsurd dicre viregularly diplayed to orer new ore the

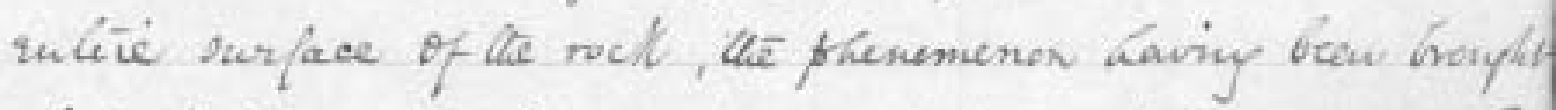

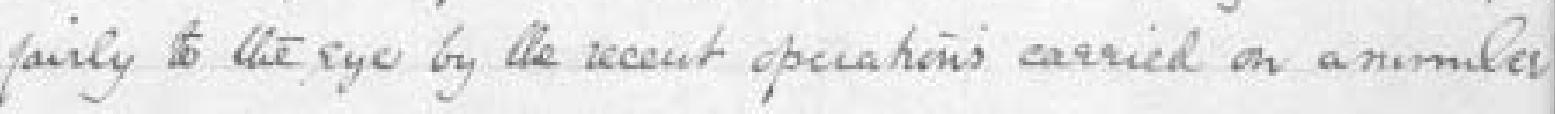

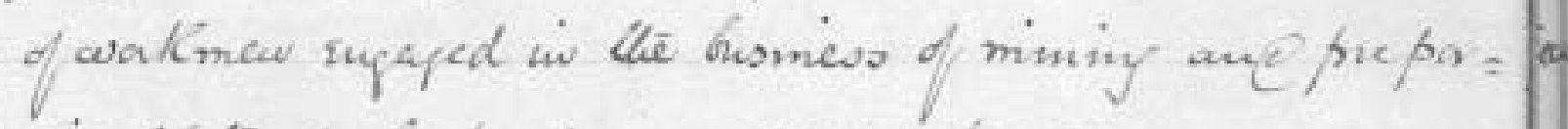
ing stater for the pingooes and we of ntaw.

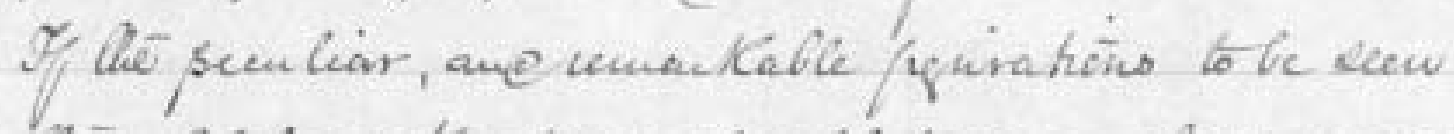

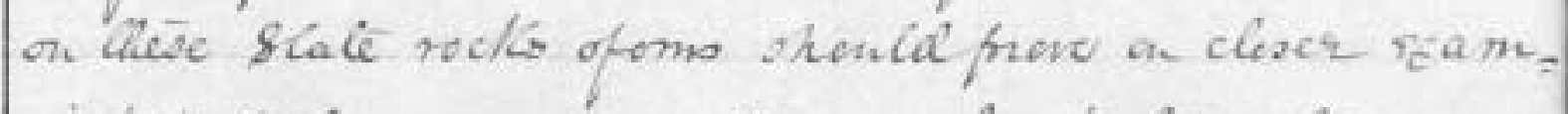

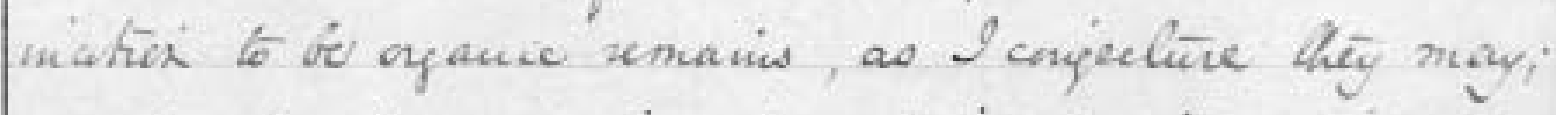

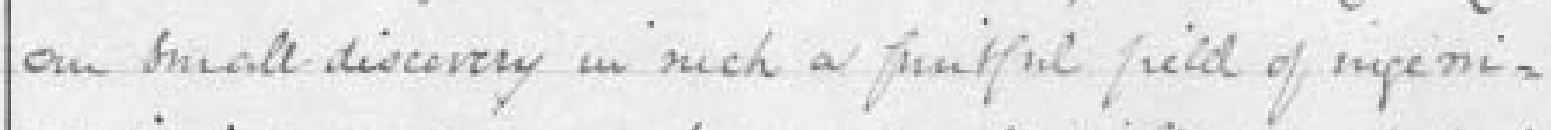
ono ingiury, are zeseavel, may walt in the bery fact of

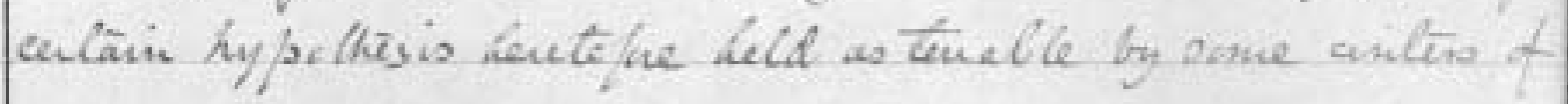



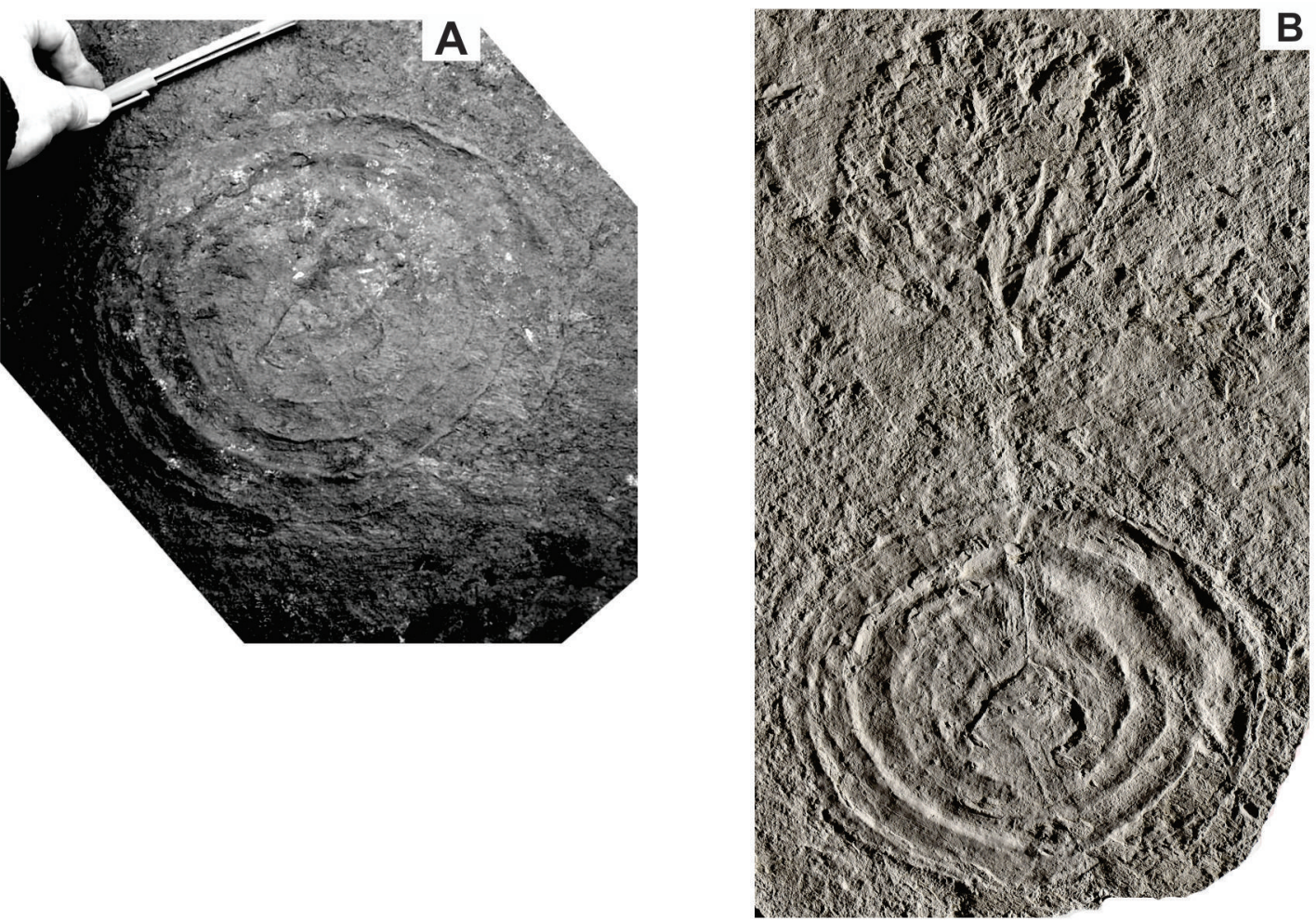

Fig. 3 
